\title{
REVISED Lightning Behaviour during the COVID-19 Pandemic
}

\section{[version 3; peer review: 2 approved]}

\section{Fazandra Yusfiandika (D1, Siow Chun Lim(D1, Chandima Gomes², Aravind Chockalingam (iD) 3 , Lee Cheng Pay ${ }^{4}$}

\author{
${ }^{1}$ Faculty of Engineering, Multimedia University, Cyberjaya, Selangor, 63100, Malaysia \\ ${ }^{2}$ School of Electrical \& Information Engineering, University of the Witwatersrand, Johannesburg, South Africa \\ ${ }^{3}$ School of Computer Science \& Engineering, Taylor's University, Subang Jaya, Selangor, Malaysia \\ ${ }^{4}$ Electrical Engineering, Duriane Professionals, Puchong, Selangor, Malaysia
}

V3 First published: 09 Sep 2021, 10:906

https://doi.org/10.12688/f1000research.70650.1

Second version: 27 Oct 2021, 10:906

https://doi.org/10.12688/f1000research.70650.2

Latest published: 03 Nov 2021, 10:906

https://doi.org/10.12688/f1000research.70650.3

\section{Abstract}

\section{Background}

COVID-19 has drastically dampened human activities since early 2020. Studies have shown that this has resulted in changes in air temperature and humidity. Since lightning activities are dependent on air temperature and humidity, this study is conducted to evaluate the correlation between the intensity of lightning activities with the atmospheric changes, and investigates the changes, in lightning activities due to atmospheric changes during the COVID-19 pandemic.

\section{Methods}

The hypothesis was tested through a t-test and Pearson's correlation study. The variation trend of lightning strikes count (LSC) in Europe and Oceania during the five months COVID-19 lockdown period (March - July) compared to the same period in the previous five years from 2015 to 2019 is investigated.

\section{Results}

Statistical analysis shows the LSC in Europe and Oceania during the lockdown period dropped significantly by more than $50 \%$ and $44 \%$ respectively compared to the same period in previous five years. Furthermore, LSC was found to be positively correlated with air temperature and relative humidity in Europe. However, in Oceania, LSC seems to be only positively correlated with air temperature but negatively correlated with relative humidity.

\section{Conclusions}

This study seems to suggest that lightning activities have significantly changed during this pandemic due to reduction in human activities.

Keywords

lightning, air temperature, relative humidity, COVID-19, thunderstorm

\section{Open Peer Review \\ Approval Status \\ version 3 \\ (revision) \\ 03 Nov 2021 \\ version 2 \\ (revision) \\ 27 Oct 2021 \\ version 1 \\ 09 Sep 2021

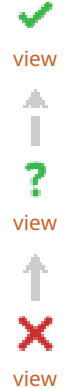 \\ 1. Francisco Javier Pérez Invernón (iD), Institut für Physik der Atmosphäre, \\ Oberpfaffenhofen, Germany \\ 2. Wooi Chin Leong (iD), Universiti Malaysia \\ Perlis, Arau, Malaysia}

Any reports and responses or comments on the article can be found at the end of the article. 


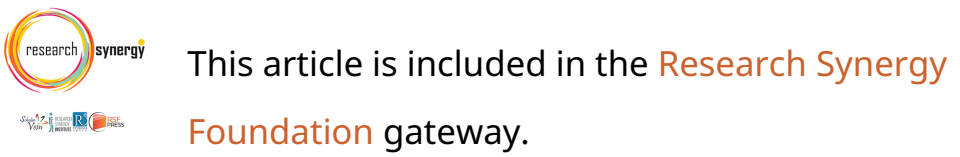

Corresponding author: Siow Chun Lim (clsiow@mmu.edu.my)

Author roles: Yusfiandika F: Conceptualization, Formal Analysis, Methodology, Writing - Original Draft Preparation, Writing - Review \& Editing; Lim SC: Conceptualization, Supervision, Writing - Review \& Editing; Gomes C: Conceptualization, Writing - Review \& Editing; Chockalingam A: Methodology, Validation; Cheng Pay L: Supervision, Validation

Competing interests: No competing interests were disclosed.

Grant information: The author(s) declared that no grants were involved in supporting this work.

Copyright: (c) 2021 Yusfiandika F et al. This is an open access article distributed under the terms of the Creative Commons Attribution License, which permits unrestricted use, distribution, and reproduction in any medium, provided the original work is properly cited.

How to cite this article: Yusfiandika F, Lim SC, Gomes C et al. Lightning Behaviour during the COVID-19 Pandemic [version 3; peer review: 2 approved] F1000Research 2021, 10:906 https://doi.org/10.12688/f1000research.70650.3

First published: 09 Sep 2021, 10:906 https://doi.org/10.12688/f1000research.70650.1 


\section{REVISED Amendments from Version 2}

We have added the following sentence to clarify our assumption of Detection Efficiency:

"It is assumed that the Detection Efficiency of the sensors used by LightningMaps.org remained constant during the period considered in this study."

Any further responses from the reviewers can be found at the end of the article

\section{Introduction}

Many countries have enforced lockdown since the beginning of the COVID-19 pandemic. ${ }^{1-3}$ Energy-intensive human activities such as travelling and the hospitality sector were drastically reduced resulting in reduced emissions of greenhouse gases. ${ }^{4}$ The global $\mathrm{CO}_{2}$ emission is estimated to drop by $8.8 \%(-1551 \mathrm{Mt})$ in the first half-year of 2020 compared to the same period in 2019. Moreover, almost $18 \%$ of $\mathrm{CO}_{2}$ emissions in recent years were produced from ground transportation.

With the exception of the preliminary findings by Jones et al., ${ }^{6}$ the general expectation by researchers is that the trend of temperature is expected to be reduced due to the reduction in $\mathrm{CO}_{2}$. A significant positive correlation between the atmospheric temperature and $\mathrm{CO}_{2}$ emission is reported in. ${ }^{7}$ Furthermore, COVID-19 lockdown has caused micro-climate changes such as localized variations in air temperature and relative humidity. ${ }^{8}$ The pandemic is also having an effect on $\mathrm{NO}_{\mathrm{X}}$, causing a decline that could possibly lead to short-term cooling. ${ }^{9}$ Air humidity will also be affected as global warming are dependent on both temperature and humidity. ${ }^{10}$ This reduction in human activities could also result in drop in aerosol level globally. This reduction in human activities could also result in drop in aerosol level globally. The result of lockdown has disrupted human and industrial activities around the world. The lockdown generally leads to a notable change in carbon dioxide $\left(\mathrm{CO}_{2}\right)$, temperature, and humidity. However, the reduction in human activities may reduce greenhouse gases and may result in a drop in global temperature. The study by Singh et al. found that implementation of lockdown reduced the percentage of temperature and may mitigate the pace of climate change in the future. ${ }^{8}$

Lightning, a natural atmospheric discharge, is affected by various environmental factors. Lightning brings about hazards to human life and appropriate risk assessment has to be conducted for any habitable structure. ${ }^{11,12}$ Atmospheric variables such as climate change, humidity, aerosol level, and wind motion can affect the cloud charge distribution, electric field and threshold electromagnetic fields that give rise to air breakdown. It is predicted that lightning may strike more frequently as a result of the ongoing climate change. ${ }^{13}$ The lightning intensity may also increase due to the high greenhouse gases in the atmosphere. However, study by Finney et al. stated that many previous studies found a positive correlation between lightning and temperature, and one previous study that found lightning decreases with an increase in temperature. ${ }^{14}$ This may explain that such relationships become highly uncertain on longer timescales. When warm, wet air rises into the cold air, thunderstorms form. As the warm air cools, moisture in the form of water vapour condenses into water droplets, a process known as condensation. Cooled air descends through the atmosphere, warms up, and rises again. A convection cell is a circuit of rising and descending air. A cloud will form if this happens in a small amount. A thunderstorm can arise if this happens with a lot of air and moisture. The presence of high air temperature and high relative humidity can quickly rise and cause powerful updrafts. These updrafts carried water droplets and quickly froze and collided with ice crystals and graupel, causing the charge transfer process.

Lightning could also be triggered by aerosols released by industrial processes and transportation activities. ${ }^{15,16}$ Aerosol could affect lightning activity through modification of cloud micro-physics. Aerosol particles serve as cloud condensation nuclei and ice nuclei, and the amount of this particles could affect the formation of cloud droplets and ice particles. More aerosol will suppress the coalescence and making the average size of cloud droplet to be reduced as well as inhibiting precipitation. Therefore, the process enables the water droplets to rise further to upper layers of the clouds and may enhance the lightning processes. During the lockdown period, many industrial sectors stopped operating. Thus, human activities have considerably reduced during the COVID-19 pandemic which may affect the rate of lightning. Lightning ground flash density tends to increase with drier and warmer surface air. ${ }^{17}$ Furthermore, the frequency of thunderstorms shows a major peak during summer time. ${ }^{19}$ Previous studies have also found a strong relationship between relative humidity and lightning occurrence. ${ }^{19,20}$ Studies from Pinto Neto et al., ${ }^{21}$ and PerezInvernon et al., ${ }^{22}$ found lightning intensity decreased drastically during lockdown period compared to previous year. This is due to the average value of aerosol which played a major role in lightning events have dropped significantly during lockdown period. Last but not least, Chowduri et al. also concurred that the reduction in particulate matter and aerosol concentration bears strong correlation with the reduction in lightning activity in Kolkata during the COVID-19 lockdown. ${ }^{23}$ 
Hence, it is of interest to investigate the correlation between the environmental changes that happened during the period of COVID-19 related restriction of human activities and the lightning occurrence density. This study is an attempt to analyse this situation. This study investigates the trend of five months of lightning occurring from March to July in 2020 compared with the same period (March-July) in 2015-2019 in Europe and Oceania. The outcomes of this work could yield interesting insights into the correlation between human activities and lightning frequency.

\section{Methods}

\section{Overview}

Lightning stroke counts (LSC) and two atmospheric factors namely air temperature and relative humidity are considered as the variables in this study. The relationship between LSC with respect to air temperature and relative humidity will be statistically analysed via the dependent t-test and Pearson correlational studies.

\section{Data description}

From March until July in Europe and Oceania, the total LSC from the year 2015 to 2020 were extracted from LightningMaps.org. ${ }^{24}$ LightningMaps.org provides historical data of LSC and has been widely used in previous studies. ${ }^{25,26}$ It is assumed that the Detection Efficiency of the sensors used by LightningMaps.org remained constant during the period considered in this study. The distribution of LSC data is presented in Tables 1 and 2.

The air temperature and relative humidity data from March until July in Europe and Oceania from year 2020 are extracted from the Physical Sciences Laboratory using Panoply Version 4.12.0. ${ }^{27}$ Europe is divided into seven sub-regions such as North Europe, West Europe, Central Europe, East Europe, South Europe, Southeast Europe, and the British Isles. After that, eight points $\left(57.5^{\circ} \mathrm{N}, 10.0^{\circ} \mathrm{E} ; 42.5^{\circ} \mathrm{N}, 12.5^{\circ} \mathrm{E} ; 50.0^{\circ} \mathrm{N}, 25.0^{\circ} \mathrm{E} ; 50.0^{\circ} \mathrm{N}, 5.0^{\circ} \mathrm{E} ; 50.0^{\circ} \mathrm{N}, 10.0^{\circ} \mathrm{E} ; 50.0^{\circ} \mathrm{N}, 20.0^{\circ} \mathrm{E}\right.$; $52.5^{\circ} \mathrm{N}, 0.0^{\circ} ; 42.5^{\circ} \mathrm{N}, 22.5^{\circ} \mathrm{E}$ ) of around the sub-regions of Europe were selected in this study. For the Oceania region, five points $\left(-12.5^{\circ} \mathrm{N}, 132.5^{\circ} \mathrm{E} ;-37.5^{\circ} \mathrm{N}, 142.5^{\circ} \mathrm{E} ;-27.5^{\circ} \mathrm{N}, 152.5^{\circ} \mathrm{E} ;-30.0^{\circ} \mathrm{N}, 115.0^{\circ} \mathrm{E} ;-27.5^{\circ} \mathrm{N}, 135.0^{\circ} \mathrm{E}\right)$ covering the North, South, East and West of Australia; Three points $\left(-37.5^{\circ} \mathrm{N}, 175^{\circ} \mathrm{E} ;-45.0^{\circ} \mathrm{N}, 167.5^{\circ} \mathrm{E} ;-42.5^{\circ} \mathrm{N}, 170.0^{\circ} \mathrm{E}\right)$ covering the North, South and Centre of New Zealand; one point $\left(-10.0^{\circ} \mathrm{N}, 147.5^{\circ} \mathrm{E}\right)$ from Papua were considered. Tables 3 and 4 show the average value of air temperature and relative humidity in Europe and Oceania in year 2020.

\section{Statistical approach}

A dependent t-test is was conducted using Microsoft Excel 2016 (Microsoft Excel, RRID:SCR_016137) to determine whether there is a statistically significant difference between the LSC during the lockdown period in the year 2020 and the LSC in the same period (March-July) in year 2015 until 2019. The LSC is measured from a single population (Europe or Oceania) and two different timelines (before and during). Period A represents the lightning activities before lockdown

Table 1. LSC in Europe (2015-2020).

\begin{tabular}{|c|c|c|c|c|c|c|c|}
\hline \multirow[t]{2}{*}{ Month } & \multirow[t]{2}{*}{ Day } & \multicolumn{6}{|l|}{ Year } \\
\hline & & 2015 & 2016 & 2017 & 2018 & 2019 & 2020 \\
\hline \multirow[t]{3}{*}{ March } & $1-10$ & 35941 & 94976 & 85347 & 80813 & 119923 & 88282 \\
\hline & $11-20$ & 92900 & 98426 & 17198 & 127512 & 112124 & 69633 \\
\hline & $21-31$ & 241800 & 57226 & 70447 & 122112 & 124324 & 130382 \\
\hline \multirow[t]{3}{*}{ April } & $1-10$ & 135720 & 147551 & 319021 & 342496 & 461290 & 67008 \\
\hline & $11-20$ & 127720 & 303901 & 137021 & 369496 & 358290 & 271908 \\
\hline & $21-30$ & 388220 & 112051 & 42021 & 1030496 & 739790 & 299408 \\
\hline \multirow[t]{3}{*}{ May } & $1-10$ & 695659 & 337627 & 475664 & 1365371 & 497596 & 426035 \\
\hline & $11-20$ & 982159 & 572627 & 1097164 & 1248870 & 1101096 & 432035 \\
\hline & $21-31$ & 827659 & 1956427 & 1807664 & 2232870 & 949296 & 481535 \\
\hline \multirow[t]{3}{*}{ June } & $1-10$ & 1999717 & 1774966 & 1753743 & 3413850 & 1808843 & 858421 \\
\hline & $11-20$ & 2140519 & 1423466 & 1058744 & 2299751 & 2531043 & 1080921 \\
\hline & $21-30$ & 636219 & 2987966 & 3270243 & 1907351 & 1555843 & 942421 \\
\hline \multirow[t]{3}{*}{ July } & $1-10$ & 2506871 & 1308306 & 2164302 & 2129821 & 2278580 & 1056066 \\
\hline & $11-20$ & 1271672 & 2028806 & 2014302 & 2183320 & 1589581 & 663066 \\
\hline & $21-31$ & 1610671 & 3076806 & 3005001 & 2908220 & 2051581 & 1207066 \\
\hline
\end{tabular}




\begin{tabular}{|c|c|c|c|c|c|c|c|}
\hline \multirow[t]{2}{*}{ Month } & \multirow[t]{2}{*}{ Day } & \multicolumn{6}{|l|}{ Year } \\
\hline & & 2015 & 2016 & 2017 & 2018 & 2019 & 2020 \\
\hline \multirow[t]{3}{*}{ March } & $1-10$ & 53851 & 114529 & 143439 & 160457 & 304771 & 107194 \\
\hline & $11-20$ & 104251 & 138479 & 255589 & 98857 & 497771 & 99195 \\
\hline & $21-31$ & 119252 & 78379 & 166239 & 177507 & 393771 & 183794 \\
\hline \multirow[t]{3}{*}{ April } & $1-10$ & 175097 & 49857 & 95565 & 162905 & 204339 & 156121 \\
\hline & $11-20$ & 147197 & 50706 & 77865 & 252705 & 120840 & 139171 \\
\hline & $21-30$ & 167797 & 56506 & 94165 & 127106 & 171840 & 98270 \\
\hline \multirow[t]{3}{*}{ May } & $1-10$ & 85097 & 49651 & 91015 & 94666 & 149871 & 122090 \\
\hline & $11-20$ & 35348 & 66301 & 92465 & 125166 & 159671 & 88940 \\
\hline & $21-31$ & 21098 & 64000 & 191704 & 139816 & 233271 & 54040 \\
\hline \multirow[t]{3}{*}{ June } & $1-10$ & 17875 & 16396 & 116735 & 57739 & 141588 & 96783 \\
\hline & $11-20$ & 14075 & 20386 & 82686 & 93488 & 92288 & 60583 \\
\hline & $21-30$ & 12475 & 52596 & 45036 & 114838 & 72338 & 73683 \\
\hline \multirow[t]{3}{*}{ July } & $1-10$ & 17891 & 32009 & 59424 & 104417 & 60083 & 134932 \\
\hline & $11-20$ & 69291 & 51699 & 92524 & 98017 & 90032 & 89333 \\
\hline & $21-31$ & 42891 & 40409 & 147474 & 135016 & 147382 & 82382 \\
\hline
\end{tabular}

Table 3. Air temperature and relative humidity in 2020 (Europe).

\begin{tabular}{|l|l|l|l|}
\hline Month & Day & $\begin{array}{l}\text { Average air } \\
\left.\text { temperature }{ }^{\circ} \mathbf{C}\right)\end{array}$ & $\begin{array}{l}\text { Average relative } \\
\text { humidity (\%) }\end{array}$ \\
\hline March & $1-10$ & 7.36 & 77.96 \\
\hline April & $11-20$ & 8.77 & 73.63 \\
\hline & $21-31$ & 10.20 & 69.12 \\
\hline May & $1-10$ & 11.39 & 67.81 \\
\hline $11-20$ & 12.22 & 69.38 \\
\hline June & $21-30$ & 13.04 & 71.16 \\
\hline $1-10$ & 14.28 & 73.47 \\
\hline July & $11-20$ & 15.33 & 76.71 \\
\hline $21-31$ & 17.57 & 80.11 \\
\hline $1-10$ & 18.69 & 80.59 \\
\hline $11-20$ & 18.99 & 78.23 \\
\hline & $21-30$ & 19.56 & 75.71 \\
\hline & $1-10$ & 20.09 & 74.82 \\
\hline $11-20$ & 20.66 & 75.25 \\
\hline
\end{tabular}

period i.e. March to July in year 2015 to 2019 . Period B represents the lightning activities during the lockdown i.e. March to July in the year 2020.

The t-test is conducted by comparing the data from Period B and Period A. The null hypothesis, $\mathrm{H}_{0}$ and the alternative hypothesis, $\mathrm{H}_{\mathrm{a}}$ is defined as below:

$\mathrm{H}_{0}$ : There is no significant difference in lightning frequency in between Period A and Period B.

$\mathrm{H}_{\mathrm{a}}$ : There is a significant difference in lightning frequency in between Period A and Period B. 


\begin{tabular}{|c|c|c|c|}
\hline Month & Day & $\begin{array}{l}\text { Average air } \\
\text { temperature }\left({ }^{\circ} \mathrm{C}\right)\end{array}$ & $\begin{array}{l}\text { Average relative } \\
\text { humidity (\%) }\end{array}$ \\
\hline \multirow[t]{3}{*}{ March } & $1-10$ & 21.18 & 72.82 \\
\hline & $11-20$ & 20.65 & 73.04 \\
\hline & $21-31$ & 20.13 & 73.34 \\
\hline \multirow[t]{3}{*}{ April } & $1-10$ & 19.38 & 73.81 \\
\hline & $11-20$ & 18.37 & 74.33 \\
\hline & $21-30$ & 17.38 & 74.74 \\
\hline \multirow[t]{3}{*}{ May } & $1-10$ & 16.67 & 75.27 \\
\hline & $11-20$ & 16.33 & 75.86 \\
\hline & $21-31$ & 16.01 & 76.46 \\
\hline \multirow[t]{3}{*}{ June } & $1-10$ & 15.69 & 76.58 \\
\hline & $11-20$ & 15.34 & 76.17 \\
\hline & $21-30$ & 15.01 & 75.79 \\
\hline \multirow[t]{3}{*}{ July } & $1-10$ & 14.98 & 75.22 \\
\hline & $11-20$ & 15.32 & 74.53 \\
\hline & $21-31$ & 15.65 & 73.82 \\
\hline
\end{tabular}

The confidence level of $95 \%$ at a significant level, $\alpha=0.05$ is used. This approach tests the hypothesis and calculates the probability of determining whether there is evidence to reject the null hypothesis. When the $P$ value $<0.05$, the null hypothesis is rejected, and vice versa.

Next, the Pearson correlation coefficient is used to evaluate the correlation between the frequency of lightning activities with the atmospheric changes. The Pearson's correlation coefficient, r, is computed to measure the strength of the relationship between total lightning strikes, air temperature, and relative humidity in Period B.

Furthermore, the correlation between the variables was analysed using regression and correlation analyses. The significant level, $\mathrm{P}$ value can be obtained from the regression data analysis. The null hypothesis, $\mathrm{H}_{0}$ and the alternative hypothesis, $\mathrm{H}_{\mathrm{a}}$ is defined as below:

Null hypothesis, $\mathrm{H}_{0}: \mathrm{P}=0$, There is no significant relationship between lightning strikes with air temperature or relative humidity.

Alternative hypothesis, $\mathrm{H}_{\mathrm{A}}: \mathrm{P} \neq 0$, There is a significant relationship between lightning strikes with air temperature or relative humidity

By using the P-value method $(\alpha=0.05)$, the decision on rejection or acceptance of the null hypothesis can be made. There is sufficient evidence to conclude that there is a significant correlation between lightning strikes and air temperature or relative humidity as the correlation coefficient is significantly different from zero. Exact $\mathrm{P}$ values and the mean value of lightning strikes from May to July are provided in Table 5.

\section{Results and discussion}

Europe

Figure 1 shows the LSC has dropped significantly in the year 2020 when the lockdown started. The dependent t-test shows a statistically significant (P-value $<0.05$ ) difference between 2020 and each previous year as shown in Table 5. Notably, LSC in Europe during the five-month lockdown period were reduced by more than $50 \%$ compared to the same period in the year 2019, 2018, and 2017.

Figure 2 illustrates the variation of LSC against air temperature levels in Europe. Figure 3. illustrates the relationship between LSC and relative humidity in Europe. Table 6 shows that the correlation of lightning strikes with air temperature and relative humidity in Europe are statistically significant. The Pearson correlation between lightning strikes and air 
Table 5. t-test results comparing lightning strikes in $\mathbf{2 0 2 0}$ with previous years in Europe.

Comparison of lightning strikes in 2020 and 2019

\begin{tabular}{|c|c|c|c|}
\hline Year & Mean & P-value & Decision \\
\hline 2020 & 538279 & $<.001$ & Reject $\mathrm{H}_{0}$ \\
\hline 2019 & 1085280 & & \\
\hline \multicolumn{4}{|c|}{ Comparison of lightning strikes in 2020 and 2018} \\
\hline Year & Mean & P-value & Decision \\
\hline 2020 & 538279 & $<.001$ & Reject $\mathrm{H}_{0}$ \\
\hline 2018 & 1450823 & & \\
\hline \multicolumn{4}{|c|}{ Comparison of lightning strikes in 2020 and 2017} \\
\hline Year & Mean & P-value & Decision \\
\hline 2020 & 538279 & .011 & Reject $\mathrm{H}_{0}$ \\
\hline 2017 & 1154525 & & \\
\hline \multicolumn{4}{|c|}{ Comparison of lightning strikes in 2020 and 2016} \\
\hline Year & Mean & P-value & Decision \\
\hline 2020 & 538279 & .016 & Reject $\mathrm{H}_{0}$ \\
\hline 2016 & 1085409 & & \\
\hline \multicolumn{4}{|c|}{ Comparison of lightning strikes in 2020 and 2015} \\
\hline Year & Mean & P-value & Decision \\
\hline 2020 & 538279 & .013 & Reject $\mathrm{H}_{0}$ \\
\hline 2015 & 912896 & & \\
\hline
\end{tabular}

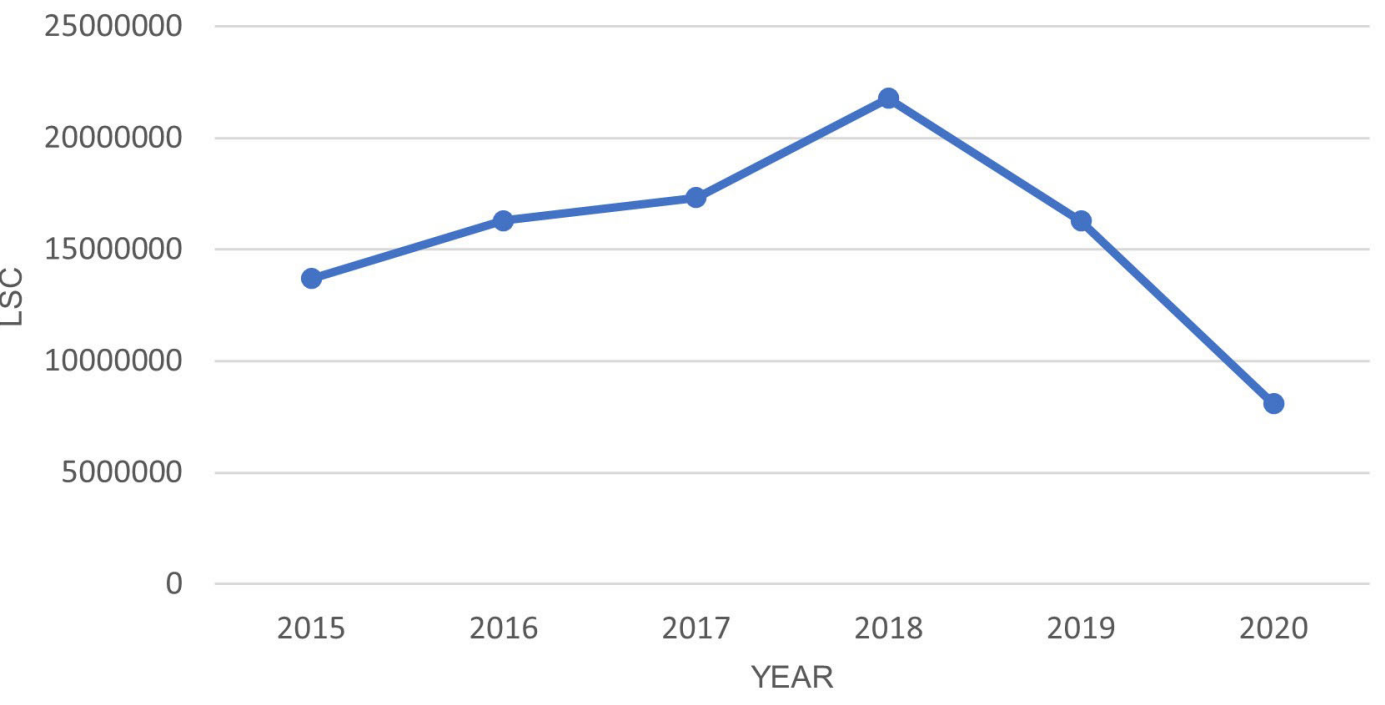

Figure 1. LSC in Europe from March-July in year 2015-2020.

temperature is 0.92 , indicating a strong positive relationship between the variables. Pearson correlation between LSC and relative humidity is 0.52 , indicating a moderate positive relationship between the variables. Higher relative humidity may enhance the upward updraft and easing the particle collision in the cloud. On the other hand, lower relative humidity may lead to weaker updraft and decreased the chance of lightning occurrence. The positive correlation between lightning strikes with air temperature and relative humidity in Europe concurs with the findings of. ${ }^{17,19,20,28,29}$ 


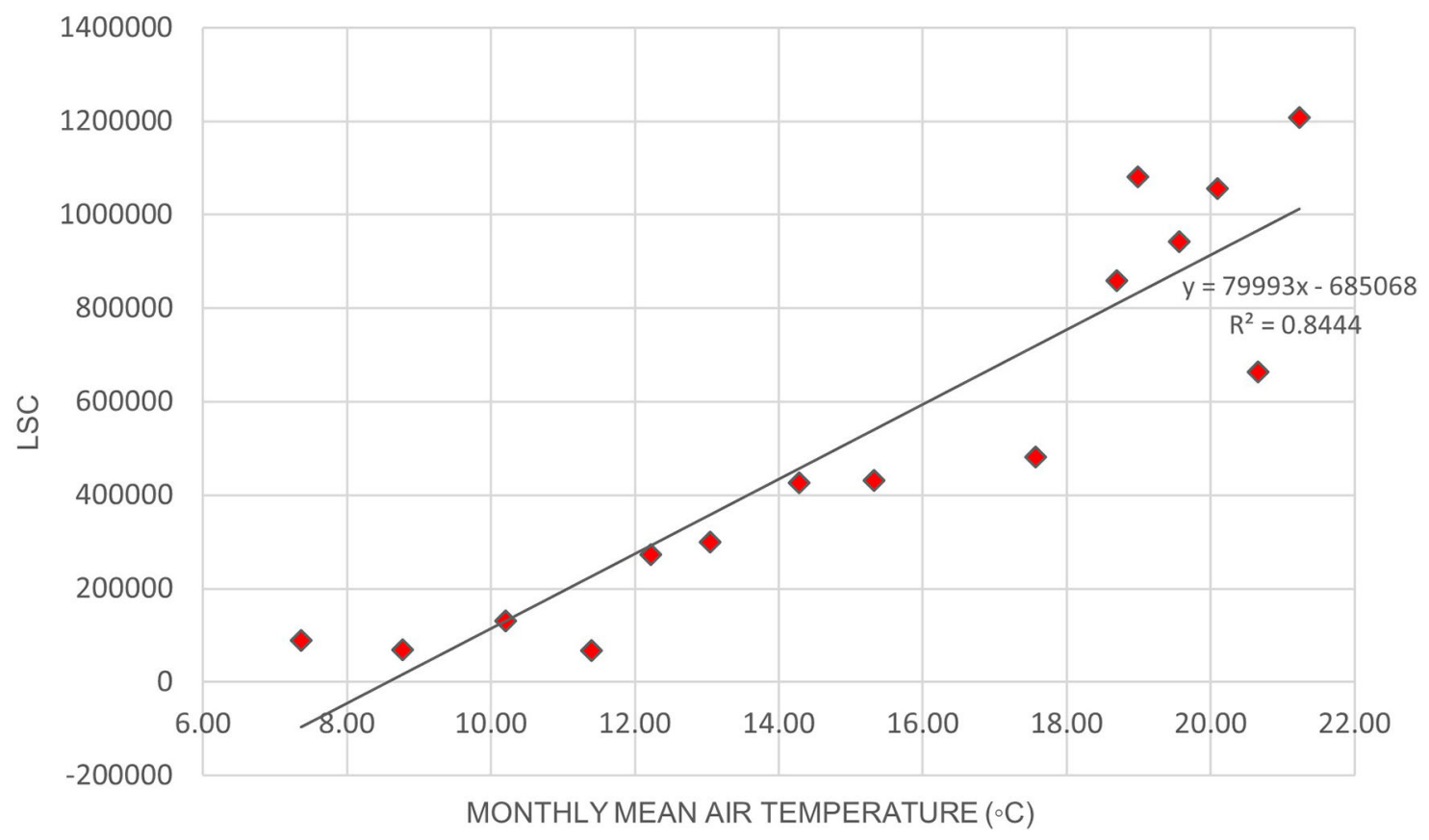

Figure 2. LSC vs air temperature over Europe during March to July 2020.

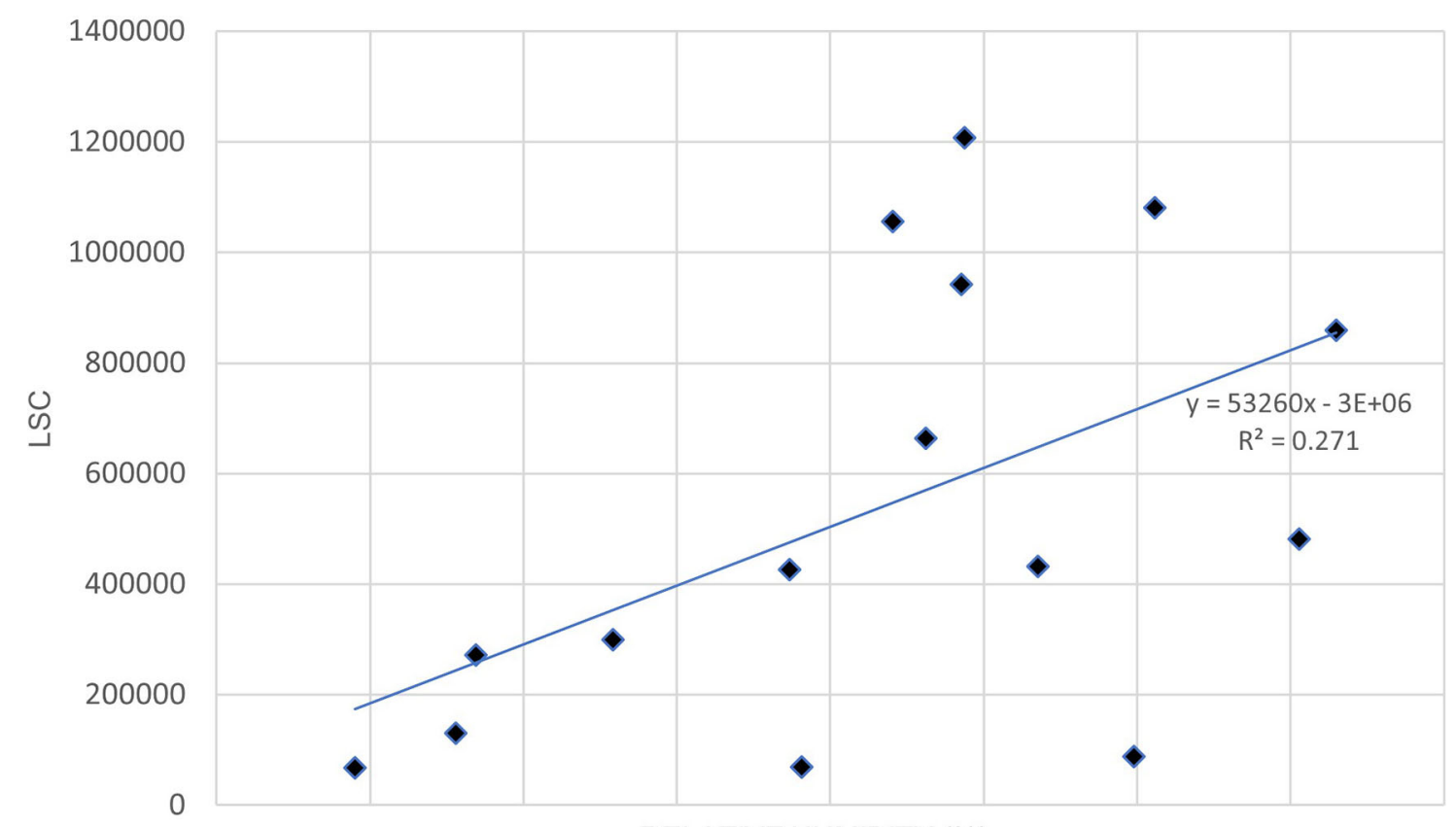

RELATIVE HUMIDITY (\%)

Figure 3. LSC vs relative humidity over Europe during March to July 2020.

Table 6. Correlation strength of lightning strikes with air temperature and relative humidity in Europe.

\begin{tabular}{|l|l|l|l|}
\hline & Correlation coefficient, $\mathbf{R}$ & P-value & Correlation strength \\
\hline Air temperature & 0.92 & $<.001$ & Very high \\
\hline Relative humidity & 0.52 & .047 & Moderate \\
\hline
\end{tabular}


Oceania

There was a 44\% drop in LSC from 2019 to 2020 as shown in Figure 4. Table 7 shows there is statistically significant difference between the year 2020 with all previous years except 2017. Figure 5 and Table 8 indicates a moderate positive correlation between LSC and air temperature in Oceania during the lockdown period. Unlike Europe, Figure 6 and Table 8 shows that the relationship between LSC and relative humidity in Oceania is negatively correlated. The positive correlation of LSC and air temperature is consistent with previous studies. ${ }^{28,29}$ The negative correlation of LSC and relative humidity in Oceania obtained in this study contradicted the study of Shi et al. ${ }^{20}$

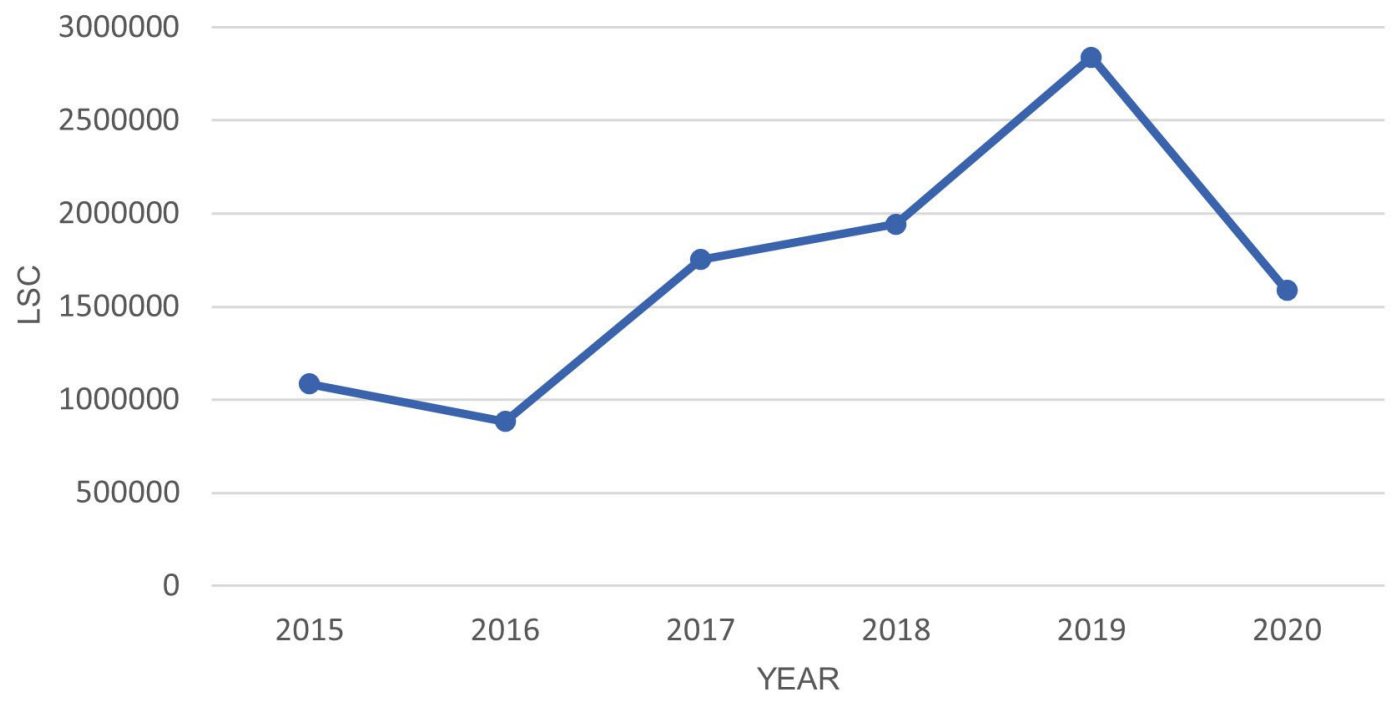

Figure 4. LSC in Oceania from March-July in year 2015-2020.

Table 7. t-test results comparing lightning strikes in 2020 with previous years in Oceania.

Comparison of lightning strikes in 2020 and 2019

\begin{tabular}{|c|c|c|c|}
\hline Year & Mean & P-value & Decision \\
\hline 2020 & 105767 & .016 & Reject $\mathrm{H}_{0}$ \\
\hline 2019 & 189324 & & \\
\hline \multicolumn{4}{|c|}{ Comparison of lightning strikes in 2020 and 2018} \\
\hline Year & Mean & P-value & Decision \\
\hline 2020 & 105767 & .050 & Reject $\mathrm{H}_{0}$ \\
\hline 2018 & 129513 & & \\
\hline \multicolumn{4}{|c|}{ Comparison of lightning strikes in 2020 and 2017} \\
\hline Year & Mean & P-value & Decision \\
\hline 2020 & 105767 & .536 & Do Not Reject $\mathrm{H}_{0}$ \\
\hline 2017 & 116795 & & \\
\hline
\end{tabular}

Comparison of lightning strikes in 2020 and 2016

\begin{tabular}{|l|l|l|l|}
\hline Year & Mean & P-value & Decision \\
\hline 2020 & 105767 & .001 & Reject $\mathrm{H}_{0}$ \\
\hline 2016 & 58794 & & \\
\hline Comparison of lightning strikes in $\mathbf{2 0 2 0}$ and 2015 & & \\
\hline Year & Mean & P-value & Decision \\
\hline 2020 & 105767 & .012 & Reject $\mathrm{H}_{0}$ \\
\hline 2015 & 72232 & & \\
\hline
\end{tabular}




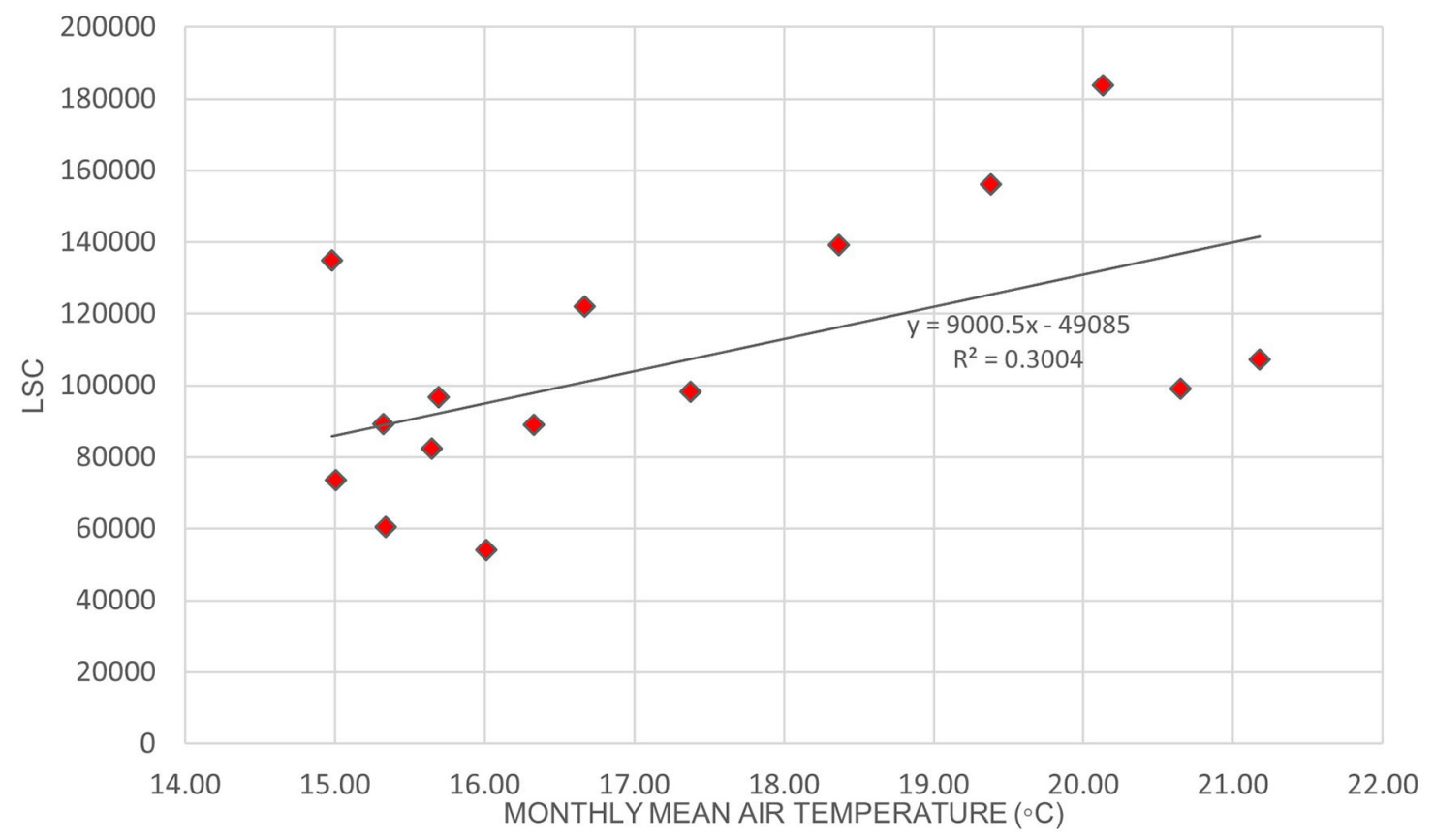

Figure 5. LSC vs air temperature over Oceania during March to July 2020.

Table 8. Correlation strength of lightning strikes with air temperature and relative humidity in Oceania.

\begin{tabular}{|l|l|l|l|}
\hline & Correlation coefficient, $\mathbf{R}$ & P-value & Correlation strength \\
\hline Air temperature & 0.55 & .034 & Moderate \\
\hline Relative humidity & -0.54 & .037 & Moderate \\
\hline
\end{tabular}

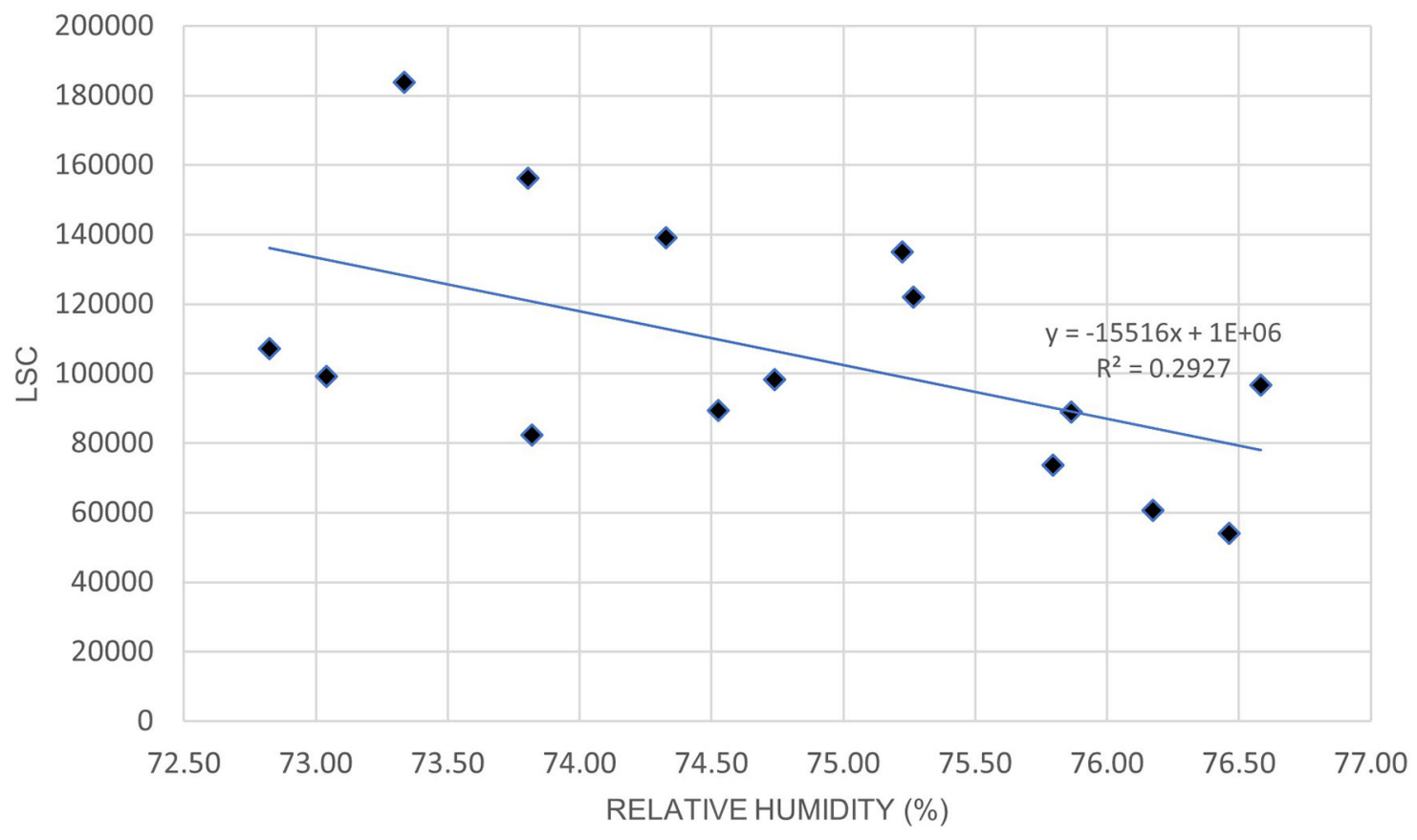

Figure 6. LSC vs relative humidity over Oceania during March to July 2020. 


\section{Conclusions}

In conclusion, there was a drastic drop in LSC in Europe and Oceania during the first lockdown period in 2020. A dependent t-test confirmed that a statistically significant difference in LSC between Period A and Period B. There is a positive relationship between LSC and air temperature in Europe $(r=0.92)$ and Oceania $(r=0.55)$. Furthermore, there is a positive relationship between LSC and relative humidity in Europe $(r=0.52)$ but a negative relationship between LSC and relative humidity in Oceania $(\mathrm{r}=-0.54)$.

The difference in correlation findings between lightning and relative humidity in Europe and Oceania remains unexplained. Higher relative humidity will lead to stronger updraft and increased lightning occurrence. However, too much vapor may weaken the updraft by blocking the vapor to rise up to complete the phase transformation.

The differences in correlation between lightning, air temperature, and relative humidity in Europe and Oceania may also be due to other possible factors such as aerosol level, wind motions, and particulate matter. Future work should be replicated in other geographical regions such as America and Asia.

\section{Author roles}

Fazandra Y: Conceptualization, Formal Analysis, Methodology, Writing - Original Draft Preparation, Writing - Review \& Editing;

Lim, S.C.: Conceptualization, Supervision, Writing - Review \& Editing

Chandima G.: Conceptualization, Writing - Review \& Editing

Aravind C.: Methodology, Validation

Lee C.P.: Validation, Supervision

Data availability statement

All data underlying the results are available as part of the article and no additional source data are required.

\section{Acknowledgements}

The authors would like to thank LightningMaps.org and National Centers for Environmental Prediction (NCEP) and National Centers for Atmospheric Research (NCAR) for providing the data for this research, and Faculty of Engineering, MMU for providing the necessary support for this study.

1. Cucinotta D, Vanelli M: WHO declares COVID-19 a pandemic. Acta Biomedica. 2020; vol. 91, no. 1. Mattioli 1885, pp. 157-160. PubMed Abstract | Publisher Full Text | Free Full Text

2. Alfano V, Ercolano S: The Efficacy of Lockdown Against COVID-19: A Cross-Country Panel Analysis. Appl. Health Econ. Health Policy.2020; 18(4): 509-517.

PubMed Abstract | Publisher Full Text | Free Full Text

3. Gautam AS, et al.: Pandemic induced lockdown as a boon to the Environment: trends in air pollution concentration across India. Asia Pac J Atmos Sci. 2021; no. March 2020.

PubMed Abstract | Publisher Full Text | Free Full Text

4. Liu Z, et al.: Near-real-time monitoring of global $\mathrm{CO} 2$ emissions reveals the effects of the COVID-19 pandemic. Nat. Commun. 2020; 11(1): 1-12.

PubMed Abstract | Publisher Full Text | Free Full Text

5. Shi $\mathrm{Z}$, Wang $\mathrm{HC}$, Tan $\mathrm{YB}$, et al.: Influence of aerosols on lightning activities in central eastern parts of China. Atmos. Sci. Lett. 2020; 21(2): 1-10.

Publisher Full Text

6. Jones CD, Hickman JE, Rumbold ST, et al.: The Climate Response to Emissions Reductions Due to COVID-19: Initial Results From CovidMIP. Geophys Res Lett. 2021; 48(8): e2020GL091883.

7. Lee H, Cheong HW: Effects of Carbon Dioxide and Clouds on Temperature. Procedia Computer Science. Jan. 2018, vol. 139, pp. 95-103.

Publisher Full Text

8. Singh M, Vikas V, Sharma C, et al.: Effect of Lockdown amid CoVID19 Pandemic on Weather Parameters of Mid Hill Region of Jammu District of J\&K, UT. Int. J. Environ. Clim. Chang. Jul. 2020: 53-77.

Publisher Full Text

9. Forster PM, et al.: Current and future global climate impacts resulting from COVID-19. Nat. Clim. Chang. Oct. 2020; 10(10): 913-919. Publisher Full Text

10. McKinnon KA, Poppick A: Estimating Changes in the Observed Relationship Between Humidity and Temperature Using Noncrossing Quantile Smoothing Splines. J. Agric. Biol. Environ. Stat. Sep. 2020; 25(3): 292-314. Publisher Full Text

11. Abulaban H, Siow C: Recent Progress on Lightning Risk Assessment and its Applications in Malaysia. Int Rev Electrical Engineering (IREE). 2021; 16 (1): 41-49. Publisher Full Text

12. Fathi MAA, Lim SC, Pay ILC: Development of a Template for the Risk Assessment for Lightning Protection System Design. 2018 34th Int Conf Lightning Protection (ICLP). 2018, pp. 1-5.

13. Romps DM, Seeley JT, Vollaro D, et al.: Projected increase in lightning strikes in the united states due to global warming. 
Science (80-.). 2014; 346(6211): 851-854 Publisher Full Text

14. Finney $\mathrm{D}$, Doherty $\mathrm{R}$, Wild $\mathrm{O}$, et al.: A projected decrease in lightning under climate change. Nat Clim Chang. 2018; 8(3): 210-213.

15. Thornton JA, Virts KS, Holzworth RH, et al.: Lightning enhancement over major oceanic shipping lanes. Geophys. Res. Lett. 2017; 44(17): 9102-9111.

Publisher Full Text

16. Pal J, Chaudhuri S, Chowdhury AR, et al.: Cloud - Aerosol interaction during lightning activity over land and ocean: Precipitation pattern assessment. Asia-Pacific J. Atmos. Sci. 2016; 52(3): 251-261. Publisher Full Text

17. Diaz-Ortiz F, Roman F: Correlation between air surface temperature and lightning events in Colombia during the last 15 years. Asia Electromagn. Conf. ASIAEM. 2015, no. August, pp. 112-115.

18. Chaudhuri S, Middey A: Comparison of tropical and midlatitude thunderstorm characteristics anchored in thermodynamic and dynamic aspects. Asia-Pacific J. Atmos. Sci. 2014; 50(2): 179-189. Publisher Full Text

19. Westermayer AT, Groenemeijer P, Pistotnik G, et al.: Identification of favorable environments for thunderstorms in reanalysis data. Meteorol. Zeitschrift.2017; 26(1): 59-70. Publisher Full Text

20. Shi Z, et al.: Effects of relative humidity on electrification and lightning discharges in thunderstorms. Terr. Atmos. Ocean. Sci. 2018; 29(6): 695-708

Publisher Full Text
21. Pinto Neto $O$, Pinto IRCA, Pinto $O$, et al.: Lightning during the COVID-19 pandemic in Brazil. J Atmos Sol Terr Phys. 2020; 211: 105463.

22. Pérez-Invernón $\mathrm{F}$, Huntrieser $\mathrm{H}$, Gordillo-Vázquez $\mathrm{F}$, et al.: Influence of the COVID-19 lockdown on lightning activity in the Po Valley. Atmos Res. 2021; 263.

23. Chowdhuri I, Pal SC, Saha A, et al.: Significant decrease of lightning activities during COVID-19 lockdown period over Kolkata megacity in India. Sci Total Environ. 2020; 747: 141321.

24. "LightningMaps.org." (accessed Mar. 06, 2021). Reference Source

25. Harvey BA: Long-Term Field Study of Lightning Surges Through Traffic Monitoring In-Pavement Sensors. IEEE Trans. Ind. Appl. 2015; 51(4): 2797-2803. Publisher Full Text

26. Garkusha IN, Hnatushenko VV, Vasyliev VV: Research of influence of atmosphere and humidity on the data of radar imaging by Sentinel-1. 2017 IEEE 37th Int. Conf. Electron. Nanotechnology, ELNANO 2017 - Proc. 2017; no. September 2018, pp. 405-408. Publisher Full Text

27. Datasets- NCEP/NCAR Reanalysis: Pressure: NOAA Physical Sciences Laboratory. (accessed Jan. 24, 2021). Reference Source

28. Price C, Asfur M: Can lightning observations be used as an indicator of upper-tropospheric water vapor variability? Bull. Am. Meteorol. Soc. 2006; 87(3): 291-298. Publisher Full Text

29. Williams ER: Lightning and climate: A review. Atmos. Res. 2005; 76(1-4): 272-287. Publisher Full Text 


\section{Open Peer Review}

\section{Current Peer Review Status:}

\section{Version 3}

Reviewer Report 04 November 2021

https://doi.org/10.5256/f1000research.78909.r98863

(C) 2021 Pérez Invernón F. This is an open access peer review report distributed under the terms of the Creative Commons Attribution License, which permits unrestricted use, distribution, and reproduction in any medium, provided the original work is properly cited.

\section{Francisco Javier Pérez Invernón}

Deutsches Zentrum für Luft- und Raumfahrt, Institut für Physik der Atmosphäre, Oberpfaffenhofen, Germany

I thank the authors for taking into consideration my comments. I think the paper can be indexed in its present form.

Competing Interests: No competing interests were disclosed.

Reviewer Expertise: Atmospheric electricity, meteorology, plasma physics.

I confirm that I have read this submission and believe that I have an appropriate level of expertise to confirm that it is of an acceptable scientific standard.

\section{Version 2}

Reviewer Report 28 October 2021

https://doi.org/10.5256/f1000research.78244.r98046

(C) 2021 Pérez Invernón F. This is an open access peer review report distributed under the terms of the Creative Commons Attribution License, which permits unrestricted use, distribution, and reproduction in any medium, provided the original work is properly cited.

\section{Francisco Javier Pérez Invernón (id}

Deutsches Zentrum für Luft- und Raumfahrt, Institut für Physik der Atmosphäre, Oberpfaffenhofen, Germany

The authors have successfully addressed most of my comments and the manuscript has 
improved.

However, I still recommend adding some statement about the Detection Efficiency (DE) of the sensors used by LightningMaps.org. The authors assumed that the DE has remained constant between 2015 and 2020 and that the observed changes in the monthly total number of lightning flashes is not an artifact. If the authors cannot check this assumption, I think they should explicitly mention that. For example, they could simply mention that they assume that the DE of the sensors used by Lightning Maps.org has remained constant during the investigated period.

Competing Interests: No competing interests were disclosed.

Reviewer Expertise: Atmospheric electricity, meteorology, plasma physics.

\section{I confirm that I have read this submission and believe that I have an appropriate level of expertise to confirm that it is of an acceptable scientific standard, however I have significant reservations, as outlined above.}

Author Response 29 Oct 2021

Chun Lim Siow, Multimedia University, Cyberjaya, Malaysia

Thank you for the recommendation to improve the quality of this manuscript.

We have added the following sentence to clarify our assumption of Detection Efficiency:

"It is assumed that the Detection Efficiency of the sensors used by LightningMaps.org remained constant during the period considered in this study."

Competing Interests: No competing interests were disclosed.

\section{Version 1}

Reviewer Report 23 September 2021

https://doi.org/10.5256/f1000research.74252.r94274

(C) 2021 Chin Leong W. This is an open access peer review report distributed under the terms of the Creative Commons Attribution License, which permits unrestricted use, distribution, and reproduction in any medium, provided the original work is properly cited.

\section{Wooi Chin Leong}

Centre of Excellence for Renewable Energy, School of Electrical Systems Engineering, Pauh Putra Campus, Universiti Malaysia Perlis, Arau, Malaysia

This is an interesting study on the lightning activities during the covid-19 pandemic periods. This 
article also relates lightning to air temperature and humidity. However, there are some parts of the article that can be further justified in order to improve the paper quality. Some suggestions have been made here:

1. What is the definition of the mean value shown in table 5 ?

2. Perhaps the authors can further explain the relationship between temperature and LSC. Why does low temperature mean less LSC etc?

3. Perhaps the authors can further explain the relationship between humidity and LSC. Why does low temperature mean less LSC etc?

4. A suggestion for the authors to discuss the relationship between months and lightning events/LSC, whether the lockdown or economic slow down affects the lightning occurrence. The authors may provide reasons to justify it as well.

Is the work clearly and accurately presented and does it cite the current literature? Yes

Is the study design appropriate and is the work technically sound? Yes

Are sufficient details of methods and analysis provided to allow replication by others? Yes

If applicable, is the statistical analysis and its interpretation appropriate? Yes

Are all the source data underlying the results available to ensure full reproducibility? Yes

Are the conclusions drawn adequately supported by the results? Yes

Competing Interests: No competing interests were disclosed.

Reviewer Expertise: Lightning

I confirm that I have read this submission and believe that I have an appropriate level of expertise to confirm that it is of an acceptable scientific standard.

Author Response 06 Oct 2021

Chun Lim Siow, Multimedia University, Cyberjaya, Malaysia

\section{Comment:}

This is an interesting study on the lightning activities during the covid-19 pandemic periods. This article also relates lightning to air temperature and humidity. However, there are some 
parts of the article that can be further justified in order to improve the paper quality. Some suggestions have been made here:

What is the definition of the mean value shown in table 5 ?

\section{Response:}

Thank you for the comment. It actually means the mean value of lightning strikes from March-July. We have added the following to clarify:

Exact $P$ values and the mean value of lightning strikes from May to July are provided in Table 5

\section{Comment:}

Perhaps the authors can further explain the relationship between temperature and LSC. Why does low temperature mean less LSC etc?

\section{Response:}

Thank you for the comment. We have added the following explanation in paragraph 3: When warm, wet air rises into cold air, thunderstorms form. As the warm air cools, moisture in the form of water vapour condenses into water droplets, a process known as condensation. Cooled air descends through the atmosphere, warms up, and rises again. A convection cell is a circuit of rising and descending air. A cloud will form if this happens in a small amount. A thunderstorm can arise if this happens with a lot of air and moisture.

The presence of high air temperature can quickly rise and cause powerful updrafts. These updrafts carried water droplets and quickly freeze and begin collision with ice crystals and graupel which causing charge transfer process. Therefore, low temperature may slow down this process.

\section{Comment:}

Perhaps the authors can further explain the relationship between humidity and LSC. Why does low temperature mean less LSC etc?

\section{Response:}

Thank you for the comment. Studies found that higher relative humidity may enhance the upward updraft and easing the particle collision in the cloud. Lower relative humidity may lead to weaker updraft and decreased the chance of lightning occurrence. This trend has been demonstrated in Europe but not in Oceania. We have added the explanation in the Results and Discussion section under Europe.

\section{Comment:}

A suggestion for the authors to discuss the relationship between months and lightning events/LSC, whether the lockdown or economic slow down affects the lightning occurrence. The authors may provide reasons to justify it as well.

\section{Response:}

Thank you for the suggestion. The introduction section has been further enhanced by incorporating additional references to support our argument. 
Competing Interests: No competing interests were disclosed.

Reviewer Report 16 September 2021

https://doi.org/10.5256/f1000research.74252.r94352

(C) 2021 Pérez Invernón F. This is an open access peer review report distributed under the terms of the Creative Commons Attribution License, which permits unrestricted use, distribution, and reproduction in any medium, provided the original work is properly cited.

\section{Francisco Javier Pérez Invernón}

Deutsches Zentrum für Luft- und Raumfahrt, Institut für Physik der Atmosphäre, Oberpfaffenhofen, Germany

This manuscript reports an analysis of the changes in lightning, temperature and relative humidity between 2015 and 2020, including the COVID-19 lockdown period. The authors find a significant change in these variables during the lockdown. They perform a statistical analysis to find possible relationships between the temperature, relative humidity and lightning. They find a possible correlation between them.

The analysis of these variables is interesting, as well as finding possible relationships between them. However, the authors do not report a solid connection between the COVID-19 pandemic and the variables.

The topic is in the scope of F1000 Research. The manuscript is well written and organized. However, references are not updated, the method needs some more clarification, and the conclusions are not supported by the results. In addition, I miss a Discussion.

I think the authors have to make a major revision before this manuscript can be accepted for indexing. If the authors cannot explain the possible relationship between the reduction of lightning and the pandemic, they may consider excluding the attribution of the decrease in lightning activity to the pandemic.

I provide specific comments below:

\section{Introduction}

Second paragraph: Please mention the reduction in aerosols during the lockdown.

The reference provided by the authors for the relationship between $\mathrm{CO} 2$ emissions and temperature reports a significant positive correlation between the atmospheric temperature and $\mathrm{CO} 2$ emission at a scale of years. Please provide some reference for a possible correlation between $\mathrm{CO} 2$ and temperature at a time period similar to the lockdown (weeks-months). Jones et al. $(2021)^{1}$ did not find any relationship between the CO2 reduction and changes in temperature. 
Third paragraph: Some authors have reported a possible decrease in lightning activity due to climate change (Finney et al., 2018) ${ }^{2}$.

Fourth paragraph: Please explain how aerosols are involved in lightning activity.

"Lightning ground flash density tends to increase with drier and warmer surface air": Please provide some reference. In general, lightning does not tend to increase with drier surface.

Why mention Denver and Colorado in this study?

Previous studies have already investigated the possible relationship between the lockdown and lightning activity. Please cite and explain them in the introduction: Chowdhuri et al. (2020) ${ }^{3}$, Pinto Neto et al. (2020) ${ }^{4}$, Pérez-Invernón et al. $(2021)^{5}$.

\section{Methods}

The authors have to estimate the temporal evolution of the lightning Detection Efficiency of the sensors used by LightningMaps.org, as you will study the temporal evolution of lightning in the data set. Lightning can increase or decrease year by year due to changes in the Detection Efficiency. The Detection Efficiency of the data set can be investigated by comparison with other lightning data set, such as LIS.

\section{Results}

Figures 2, 3, 5 and 6: What does each point represent?

\section{General comments and conclusions}

This study shows that there could be a possible relationship between temperature, relative humidity and lightning in the studied regions (Europe and Oceania). However, the influence of the COVID-19 pandemic is not clear. There were significant changes in both temperature and relative humidity during the pandemic that could influence lightning. However, such changes could not be connected to the pandemic. See for example Jones et al. (2021) ${ }^{1}$, who used 12 models to produced over 300 simulations. They did not find any associated impact of the reduction of $\mathrm{CO} 2$ on temperature or rainfall. Changes observed in temperature and relative humidity can be due to other factors instead of the pandemic.

In addition, the authors find an opposite correlation between relative humidity and lightning in Europe and Oceania. The reasons for this opposite relationship are not explained.

Finally, previous studies have found a connection between the reduction of lightning and the reduction in the concentration of aerosols during the pandemic. However, this study does not investigate the role of aerosols in lightning activity.

\section{References}

1. Jones CD, Hickman JE, Rumbold ST, Walton J, et al.: The Climate Response to Emissions Reductions Due to COVID-19: Initial Results From CovidMIP.Geophys Res Lett. 2021; 48 (8): 
e2020GL091883 PubMed Abstract | Publisher Full Text

2. Finney $D$, Doherty $R$, Wild $O$, Stevenson $D$, et al.: A projected decrease in lightning under climate change. Nature Climate Change. 2018; 8 (3): 210-213 Publisher Full Text

3. Chowdhuri I, Pal SC, Saha A, Chakrabortty R, et al.: Significant decrease of lightning activities during COVID-19 lockdown period over Kolkata megacity in India.Sci Total Environ. 2020; 747:

141321 PubMed Abstract | Publisher Full Text

4. Pinto Neto O, Pinto IRCA, Pinto O: Lightning during the COVID-19 pandemic in Brazil.J Atmos Sol Terr Phys. 2020; 211: 105463 PubMed Abstract | Publisher Full Text

5. Pérez-Invernón F, Huntrieser H, Gordillo-Vázquez F, Soler S: Influence of the COVID-19 lockdown on lightning activity in the Po Valley. Atmospheric Research. 2021; 263. Publisher Full Text

Is the work clearly and accurately presented and does it cite the current literature?

Partly

Is the study design appropriate and is the work technically sound?

Partly

Are sufficient details of methods and analysis provided to allow replication by others? Yes

If applicable, is the statistical analysis and its interpretation appropriate?

Partly

Are all the source data underlying the results available to ensure full reproducibility? Yes

Are the conclusions drawn adequately supported by the results?

No

Competing Interests: No competing interests were disclosed.

Reviewer Expertise: Atmospheric electricity, meteorology, plasma physics.

I confirm that I have read this submission and believe that I have an appropriate level of expertise to state that I do not consider it to be of an acceptable scientific standard, for reasons outlined above.

Author Response 06 Oct 2021

Chun Lim Siow, Multimedia University, Cyberjaya, Malaysia

General Comments:

This manuscript reports an analysis of the changes in lightning, temperature and relative humidity between 2015 and 2020, including the COVID-19 lockdown period. The authors find a significant change in these variables during the lockdown. They perform a statistical analysis to find possible relationships between the temperature, relative humidity and 
lightning. They find a possible correlation between them.

The analysis of these variables is interesting, as well as finding possible relationships between them. However, the authors do not report a solid connection between the COVID19 pandemic and the variables.

The topic is in the scope of F1000 Research. The manuscript is well written and organized. However, references are not updated, the method needs some more clarification, and the conclusions are not supported by the results. In addition, I miss a Discussion.

I think the authors have to make a major revision before this manuscript can be accepted for indexing. If the authors cannot explain the possible relationship between the reduction of lightning and the pandemic, they may consider excluding the attribution of the decrease in lightning activity to the pandemic.

\section{Response to General Comments:}

Thank you for the comment. The focus of this manuscript is more on examining any statistical relationship between the lightning activities and the changes in atmospheric temperature and humidity during the pandemic. Discussion is partially included with the results and in the conclusion. At this point of research, we could only discuss it statistically and refer to any concurring literature. We have addressed the comments and incorporated the recommendations at our level best.

I provide specific comments below:

\section{Comment: Introduction}

The reference provided by the authors for the relationship between $\mathrm{CO} 2$ emissions and temperature reports a significant positive correlation between the atmospheric temperature and $\mathrm{CO} 2$ emission at a scale of years. Please provide some reference for a possible correlation between $\mathrm{CO} 2$ and temperature at a time period similar to the lockdown (weeks-months). Jones et al. (2021) did not find any relationship between the CO2 reduction and changes in temperature.

\section{Response:}

Thank you for the comment. The recommended reference has been cited. However, we could not find any reference for similar time period to the lockdown. Here is our response:

The release of carbon dioxide (CO2) from the combustion of coal, oil, and natural gas is the primary driver of rising global temperatures. These activities, as can be seen, tend to decrease during the lockdown period. As a result, the rate of temperature rise may be delayed during the lockdown period. This, however, is insufficient to cause long-term effects on $\mathrm{CO} 2$ levels and climate change on a worldwide scale.

\section{Comment:}

Third paragraph: Some authors have reported a possible decrease in lightning activity due 
to climate change (Finney et al., 2018).

Response:

Thank you for the comment. The recommended reference has been cited. Here is our response:

(Finney et al., 2018) stated that many previous studies found a positive correlation between lightning and temperature, and one previous study that found lightning decreases with an increase in temperature. This may explain that such relationships become highly uncertain on longer timescales.

\section{Comment:}

Fourth paragraph: Please explain how aerosols are involved in lightning activity.

\section{Response:}

Thank you for the comment. The following has been added into fourth paragraph:

Aerosol could affect lightning activity through modification of cloud micro-physics.

Aerosol particles serve as cloud condensation nuclei and ice nuclei, and the amount of this particles could affect the formation of cloud droplets and ice particles. More aerosol will suppress the coalescence and making the average size of cloud droplet to be reduced as well as inhibiting precipitation. Therefore, the process enables the water droplets to rise further to upper layers of the clouds and may enhance the lightning processes.

\section{Comment:}

"Lightning ground flash density tends to increase with drier and warmer surface air": Please provide some reference. In general, lightning does not tend to increase with drier surface.

\section{Response:}

Thank you for the comment. We have provided reference based on the study from DiazOrtiz reference number 17 into third paragraph:

Yes, in general lightning does not tend to increase with warmer and drier surface, but the presence of high air temperature can quickly rise and cause powerful updrafts. These updrafts carried water droplets and quickly freeze and begin collision with ice crystals and graupel which causing charge transfer process. Therefore, low temperature may slow down this process. So high temperature can be a driving factor to lightning formation.

\section{Comment:}

Why mention Denver and Colorado in this study?

\section{Response:}

Thank you for the comment.

Denver and Colorado have stated that lightning peaked during summer time, which may possibly explain the high temperature leads to high lightning activity. 


\section{Comment:}

Previous studies have already investigated the possible relationship between the lockdown and lightning activity. Please cite and explain them in the introduction: Chowdhuri et al. (2020), Pinto Neto et al. (2020), Pérez-Invernón et al. (2021).

\section{Response:}

Thank you for the comment. All the recommended articles are relevant and have been cited and explained accordingly.

\section{Comment: Methods}

The authors have to estimate the temporal evolution of the lightning Detection Efficiency of the sensors used by Lightning Maps.org, as you will study the temporal evolution of lightning in the data set. Lightning can increase or decrease year by year due to changes in the Detection Efficiency. The Detection Efficiency of the data set can be investigated by comparison with other lightning data set, such as LIS.

\section{Response:}

Thank you for the comment. Currently, this is beyond our scope of work. We will consider this for our future work.

\section{Comment: Results}

Figures 2, 3, 5 and 6: What does each point represent?

\section{Response:}

Thank you for the comment. Each point represents the lightning strikes count (LSC). Figure 2 and 5 is the scatter plots of the LSC against air temperature. Figure 3 and 6 is the scatter plots of the LSC against humidity.

\section{General comments and conclusions}

This study shows that there could be a possible relationship between temperature, relative humidity and lightning in the studied regions (Europe and Oceania). However, the influence of the COVID-19 pandemic is not clear. There were significant changes in both temperature and relative humidity during the pandemic that could influence lightning. However, such changes could not be connected to the pandemic. See for example Jones et al. (2021), who used 12 models to produced over 300 simulations. They did not find any associated impact of the reduction of $\mathrm{CO} 2$ on temperature or rainfall. Changes observed in temperature and relative humidity can be due to other factors instead of the pandemic.

\section{Response:}

Thank you for the comment. We acknowledged the findings by Jones et al. (2021) as highlighted. However, we have supplemented our argument with a few supporting references.

\section{Comment:}

In addition, the authors find an opposite correlation between relative humidity and 
lightning in Europe and Oceania. The reasons for this opposite relationship are not explained.

\section{Response:}

Thank you for the comment. Unfortunately, it is beyond our current level of understanding to provide the exact explanation on the opposite relationship found.

Higher relative humidity will lead to stronger updraft and increased lightning occurrence.

However, too much vapor may weaken the updraft by blocking the vapor to rise up to complete the phase transformation.

\section{Comment:}

Finally, previous studies have found a connection between the reduction of lightning and the reduction in the concentration of aerosols during the pandemic. However, this study does not investigate the role of aerosols in lightning activity.

\section{Response:}

Thank you for the comment. Yes, we have not considered in this in this study. However, we have noted your recommendation and have since enhanced the literature review of this study based on your feedback. We will consider the role of aerosols in lightning activity in our future work.

Competing Interests: No competing interests were disclosed.

The benefits of publishing with F1000Research:

- Your article is published within days, with no editorial bias

- You can publish traditional articles, null/negative results, case reports, data notes and more

- The peer review process is transparent and collaborative

- Your article is indexed in PubMed after passing peer review

- Dedicated customer support at every stage

For pre-submission enquiries, contact research@f1000.com 